\title{
Characteristics of patients with severe, uncontrolled, eosinophilic asthma enrolled in a French cohort
}

This article was published in the following Dove Press journal: Journal of Asthma and Allergy

\author{
Michel Aubier ${ }^{1-4}$ \\ Gabriel Thabut ${ }^{1-3,5}$ \\ Caroline Fabry-Vendrand ${ }^{6}$ \\ 'Inserm UMRII52, Physiopathology \\ and Epidemiology of Respiratory \\ Diseases, Paris, France; ${ }^{2}$ Faculty of \\ Medicine, Paris Diderot University, \\ Paris, France; ${ }^{3}$ Laboratory of \\ Excellence, INFLAMEX, Université \\ Sorbonne Paris Cité and DHU \\ FIRE, Paris, France; ${ }^{4}$ Pneumology A \\ Department, Bichat-Claude-Bernard \\ University Hospital, Paris, France; \\ ${ }^{5}$ Pneumology B Department, Bichat- \\ Claude-Bernard University Hospital, \\ Paris, France; ${ }^{6}$ Epidemiology and \\ Research Partnerships, AstraZeneca, \\ Courbevoie, France
}

Background and objective: Benralizumab (Fasenra ${ }^{\mathrm{TM}}$ ) has recently been approved as add-on maintenance treatment for adult patients with severe eosinophilic asthma inadequately controlled despite high-dosage inhaled corticosteroids plus long-acting $\beta_{2}$-agonists. We aimed to identify and describe the clinical characteristics and disease burden of patients with severe, uncontrolled, eosinophilic asthma in France who may be eligible for treatment with benralizumab.

Patients and methods: This was a retrospective analysis of a prospective, noninterventional, observational study of patients in France enrolled in the Asthma and Bronchial Obstruction Cohort (COBRA). First, we selected adult patients with severe asthma, a documented blood eosinophil count, 12 months of baseline data, and 12 months of follow-up data. Of these studyeligible patients, we next determined the prevalence and described the clinical characteristics and disease burden of patients who would be eligible to receive benralizumab, namely those with $\geq 2$ asthma exacerbations in the previous 12 months and a blood eosinophil count $\geq 300 / \mu \mathrm{L}$ who were receiving high-dosage inhaled corticosteroids/long-acting $\beta_{2}$-agonists.

Results: Of the 441 patients eligible for this study, 85 (19\%) met the criteria for benralizumab therapy. At study inclusion, benralizumab-eligible patients had a smaller prebronchodilator forced expiratory volume in 1 second and less effective asthma control compared with benralizumab-ineligible patients. During the 12-month follow-up period, benralizumab-eligible patients had greater frequencies of asthma exacerbations and hospitalizations compared with benralizumab-ineligible patients.

Conclusion: Of patients with severe asthma, approximately $20 \%$ were qualified for benralizumab treatment. Benralizumab-eligible patients had increased bronchial obstruction, worse asthma control, and a greater frequency of asthma exacerbations and hospitalizations during follow-up care compared with benralizumab-ineligible patients, demonstrating inadequate disease control for these patients.

Keywords: COBRA, benralizumab, biologic, eosinophilia, France

\section{Introduction}

France has one of the highest prevalences of asthma worldwide, approaching 7\% in the adult population. ${ }^{1,2} \mathrm{Up}$ to $10 \%$ of adult patients with asthma have severe asthma, which require treatment with high-dosage inhaled corticosteroids (ICS) plus longacting $\beta_{2}$-agonists (LABA) to control their disease. ${ }^{3} \mathrm{~A}$ further subset of patients has uncontrolled asthma symptoms despite these treatments. These uncontrolled symptoms, which place patients at high risk for asthma exacerbations, hospitalizations, and diminished health-related quality of life, are associated with significant health care costs. ${ }^{4}$ The annual cost of severe asthma rises with decreasing asthma control and can reach $€ 2,000$ per patient year in France. ${ }^{5}$
Correspondence: Michel Aubier Service de Pneumologie B, Inserm UII52, Faculté de Médecine Paris Diderot, Hôpital Bichat-Claude-Bernard, 16 rue Henri Huchard, Paris 75018 , France Tel $+33 \quad 140256800$ Fax +330140258305 Email michel.aubier@inserm.fr 
Additional therapeutics are needed to control severe asthma for patients who do not respond well to conventional anti-inflammatory treatment. Targeted therapeutics are effective add-on treatments, particularly when patients are selected using appropriate biomarkers (eg, high blood eosinophil counts). ${ }^{6}$ Eosinophilia is associated with asthma severity and poor asthma control. ${ }^{7-9}$ Benralizumab is a humanized, afucosylated IL-5 receptor alpha-directed cytolytic monoclonal antibody that induces direct, rapid, and nearly complete depletion of eosinophils via enhanced antibody-dependent cell-mediated cytotoxicity. ${ }^{10}$ In phase III trials (SIROCCO [NCT01928771] and CALIMA [NCT01914757]), benralizumab in combination with highdosage ICS/LABA significantly reduced annual asthma exacerbation rates and improved lung function and asthma control for patients with severe, uncontrolled asthma with eosinophilia. ${ }^{11,12}$ In the EU, benralizumab (Fasenra ${ }^{\mathrm{TM}}$, AstraZeneca $\mathrm{AB}$, Södertälje, Sweden) is indicated for add-on maintenance treatment of adult patients with severe eosinophilic asthma inadequately controlled despite high-dosage ICS/LABA. ${ }^{13}$

The objectives of this study were to determine the prevalence and describe the clinical characteristics and disease burden of adult patients in France with severe, uncontrolled asthma who may be eligible for benralizumab treatment based on SIROCCO/CALIMA enrollment (high-dosage ICS/ LABA, $\geq 2$ asthma exacerbations in the prior 12 months) and stratification criteria (blood eosinophil counts $\geq 300$ cells $/ \mu \mathrm{L}$ ). Patients eligible for this study were derived from the Asthma and Bronchial Obstruction Cohort (COBRA), a French multicenter, prospective cohort of patients that includes those with COPD and approximately 1,000 patients with asthma. ${ }^{14,15}$

\section{Material and methods}

\section{Study design and participants}

This study was a retrospective analysis of the COBRA study, an ongoing French multicenter, prospective, noninterven- tional, observational study of adult patients $(\geq 18-80$ years old) with either asthma or COPD with 10 years of followup. ${ }^{14,15} \mathrm{~A}$ detailed description of the COBRA study design has been published. ${ }^{15}$ Patients were enrolled into COBRA regardless of disease severity. Data and biological sample collection began in March 2008.

Data extraction for this study occurred on December 9, 2015. To be eligible for this retrospective study, patients in COBRA were required to have severe asthma (defined as requiring Global Initiative for Asthma [GINA] step 4 or 5 treatment), documented blood eosinophil counts, and at least 12 months of follow-up data (Figure 1). Study-eligible patients were considered for benralizumab treatment if they were receiving high-dosage ICS/LABA, had experienced $\geq 2$ asthma exacerbations that required treatment with systemic corticosteroids in the year prior to the index date, and had blood eosinophil counts $\geq 300$ cells $/ \mu \mathrm{L}$ (Figure 1).

Baseline data for patient characterization were collected for one year prior to the index date (visit 1; Figure 1) and included patient demographics, comorbidities, treatment, asthma severity, asthma exacerbations, emergency department visits, and hospitalizations. Blood eosinophil counts were obtained at and after the index date. One year of outcome data after the index date was extracted as well.

\section{Outcomes}

The objectives of this analysis were to determine the prevalence and describe the clinical characteristics and disease burden of patients with severe asthma in the COBRA cohort who were eligible for benralizumab treatment based on SIROCCO/CALIMA enrollment and stratification criteria. Endpoints to describe disease burden were the number of asthma exacerbations, asthma-related emergency department visits, and asthma-related hospitalizations during the 12-month period post index date. Asthma exacerbations were defined as a worsening of asthma requiring the use

Table I Characteristics of the study sample $(\mathrm{N}=44 \mathrm{I})$

\begin{tabular}{|c|c|c|}
\hline Criteria & $\begin{array}{l}\text { No } \\
\text { n (\%) }\end{array}$ & $\begin{array}{l}\text { Yes } \\
\text { n (\%) }\end{array}$ \\
\hline$\geq 2$ asthma exacerbations in previous 12 months & $211(48)$ & $230(52)$ \\
\hline Eosinophil count $\geq 300$ cells/ $\mu \mathrm{L}$ & $267(6 I)$ & $174(40)$ \\
\hline High-dosage ICS/LABA & $118(27)$ & $323(73)$ \\
\hline All three criteria together (benralizumab eligibility) & $356(8 I)$ & $85(19)$ \\
\hline High-dosage ICS/LABA AND $\geq 2$ asthma exacerbations in previous 12 months & $254(58)$ & $187(42)$ \\
\hline \multicolumn{3}{|l|}{ High-dosage ICS/LABA AND $\geq 2$ asthma exacerbations in previous 12 months AND } \\
\hline Eosinophil count $\geq 100$ cells $/ \mu \mathrm{L}$ & $292(66)$ & $149(34)$ \\
\hline Eosinophil count $\geq 150$ cells $/ \mu \mathrm{L}$ & $312(7 \mid)$ & $129(29)$ \\
\hline Eosinophil count $\geq 300$ cells/ $\mathrm{\mu L}$ & $356(81)$ & $85(19)$ \\
\hline Eosinophil count $\geq 400$ cells $/ \mu \mathrm{L}$ & $379(86)$ & $62(14)$ \\
\hline
\end{tabular}

Abbreviations: ICS, inhaled corticosteroids; LABA, long-acting $\beta_{2}$-agonists. 


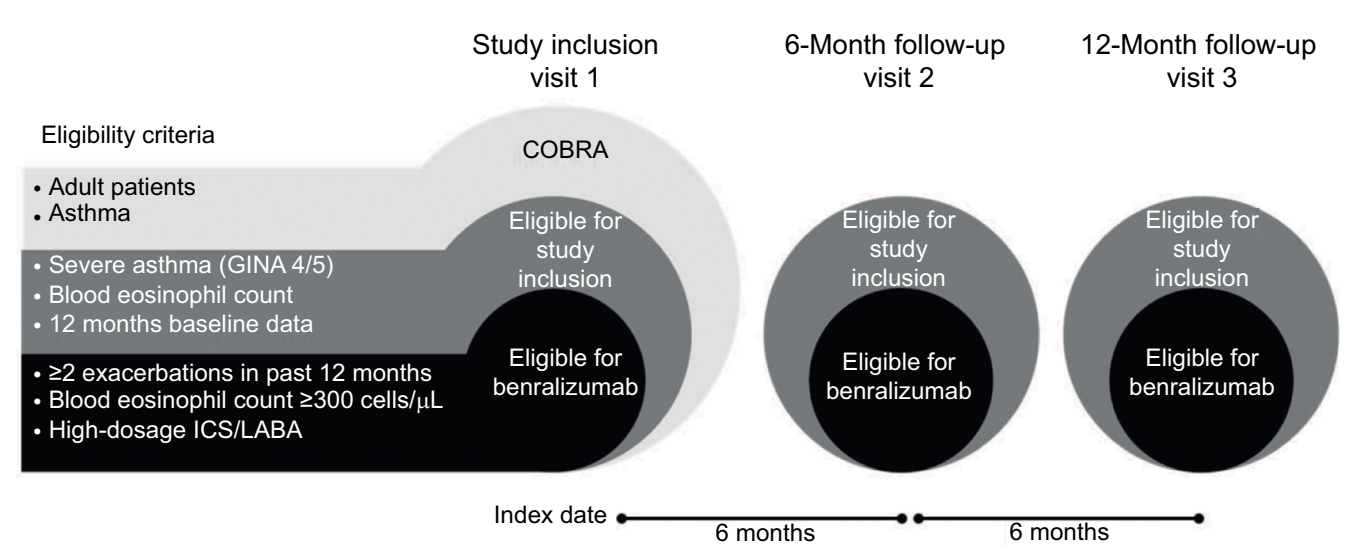

Figure I Eligibility criteria and study design.

Abbreviations: COBRA, Asthma and Bronchial Obstruction Cohort; GINA, Global Initiative for Asthma; ICS, inhaled corticosteroids; LABA, long-acting $\beta_{2}$-agonists.

of systemic corticosteroids (or a temporary increase in a stable oral corticosteroid background dose) for at least three days. The level of asthma control was assessed by the Asthma Control Questionnaire (ACQ). Optimal asthma control was defined as ACQ scores $\leq 0.5$, suboptimal asthma control as scores $>0.5-1.5$, and unacceptable asthma control as scores $>1.5 .{ }^{15}$

\section{Statistical analysis}

Data were entered in the COBRA database using an electronic case report form. Stata ${ }^{\circledR}$ software (StataCorp LLC, College Station, TX, USA), version 13.1, and R software, version 2.15.2 (The R Foundation for Statistical Computing, Vienna, Austria), were used for data management and data analysis, respectively. Continuous variables were summarized with descriptive statistics (number, mean, SD, range, and median), and frequency counts and percentages within each category were provided for categorical data. Asthma exacerbations and hospitalizations were expressed as rates (number per year) and as percentage of patients having at least one event. Emergency department visits were expressed as the percentage of patients having at least one emergency department visit during follow-up. Estimates for one year of follow-up were derived from visits that occurred during the 9-15-month interval range, with rates annualized. When possible, missing data were obtained from the patients' medical records. Statistics were computed for patients with available (nonmissing) data. No imputation was performed. Characteristics of patients eligible for benralizumab treatment were compared with those of benralizumab-ineligible patients using nonparametric tests:
Fisher's exact test and Mann-Whitney U test for categorical and continuous variables, respectively. Asthma exacerbation rates were analyzed by Poisson regression models with the logarithm of follow-up as an offset variable. Differences between groups were considered statistically significant if $P$-values were $<0.05$. No attempt was made to adjust for multiple comparisons.

\section{Ethics approval and informed consent}

The COBRA study was approved by the Comités de Protection des Personnes Ile-de-France I (number 09-11962), and all patients gave their written informed consent before being enrolled.

\section{Results}

Of 1,081 patients in the COBRA database, 441 patients recruited from nine hospitals fulfilled the study inclusion criteria of having severe asthma, at least one year of followup data, and documented blood eosinophil counts (Table 1). During the year prior to the index date, 230 (52\%) of the 441 patients experienced $\geq 2$ asthma exacerbations that required treatment with systemic corticosteroids, 187 patients (42\%) also received high-dosage ICS/LABA, and 85 patients (19\%) also had blood eosinophil counts $\geq 300$ cells $/ \mu \mathrm{L}$. Thus, $19 \%$ of adult patients with severe asthma in the COBRA study met the eligibility criteria for benralizumab therapy.

Patient demographics were similar between benralizumab-eligible and -ineligible patients and were representative of patients with severe asthma (Table 2). The median ages for benralizumab-eligible and -ineligible patients were 50 years and 53 years, respectively $(P=0.10)$. 
Most patients were white (benralizumab-eligible patients: $74 \%$, benralizumab-ineligible patients: $81 \%$ ), and more than half of the patients in each group were female (benralizumabeligible patients: $67 \%$, benralizumab-ineligible patients: $68 \% ; P=0.90)$. Mean predicted prebronchodilator forced expiratory volume in 1 second $\left(\mathrm{FEV}_{1}\right)$ was smaller for benralizumab-eligible patients than for benralizumab-ineligible patients ( $70 \%$ vs $76 \%$, respectively; $P=0.03$; Table 3 ).

At study inclusion, benralizumab-eligible patients had less effective asthma control than benralizumab-ineligible patients (optimal in $5 \%$ of patients vs $23 \%$ of patients, respectively; $P<0.001$; Table 2). Benralizumab-eligible patients had a higher mean number of asthma exacerbations in the previous 12 months compared with benralizumab-ineligible patients (6.9 vs 2.7, respectively; $P<0.001$; Table 2 ). The percentage of benralizumab-eligible patients who experienced asthma "attacks" (interpreted by patients as an asthma crisis) was greater than that of benralizumab-ineligible patients (Table 2; $P=0.02$ ).

Benralizumab-eligible patients had a greater prevalence of nasal polyposis ( $42 \%$ vs $22 \% ; P=0.003$ ), greater use of ICS/LABA/long-acting muscarinic antagonists (LAMA) $(21 \%$ vs $12 \% ; P=0.03)$ and antileukotriene agents $(47 \%$ vs $31 \% ; P=0.01)$. Both LAMA ( $21 \%$ vs $13 \% ; P=0.06)$ and oral corticosteroid ( $27 \%$ vs $19 \% ; P=0.13$ ) use by benralizumabeligible patients were greater than benralizumab-ineligible

Table 2 Demographics and baseline clinical characteristics of COBRA patients with severe asthma at study inclusion

\begin{tabular}{|c|c|c|c|}
\hline Demographics and baseline clinical characteristics & $\begin{array}{l}\text { Benralizumab- } \\
\text { ineligible patients } \\
(n=356)\end{array}$ & $\begin{array}{l}\text { Benralizumab- } \\
\text { eligible patients } \\
(n=85)\end{array}$ & $P$-value \\
\hline Median age, years (IQR) & $53(40-62)$ & $50(40-57)$ & 0.10 \\
\hline Female, n (\%) & $241(68)$ & $57(67)$ & 0.90 \\
\hline Mean body mass index, $\mathrm{kg} / \mathrm{m}^{2}(\mathrm{SD})$ & $27.3(6.1)$ & $26.7(5.9)$ & 0.24 \\
\hline \multicolumn{4}{|l|}{ Smoking habits, $\mathrm{n}(\%)$} \\
\hline Current smoker & $33(9)$ & $2(2)$ & 0.08 \\
\hline Past smoker & $104(29)$ & $25(29)$ & \\
\hline Never-smoker & $218(61)$ & $58(68)$ & \\
\hline Median smoking history, pack-years (IQR) & $10.0(5.0-20.0)$ & $5.5(5.0-13.8)$ & 0.40 \\
\hline Median age at asthma onset, years (IQR) & $20(6-40)$ & $29(17-43)$ & 0.007 \\
\hline Median duration of asthma disease, years (IQR) & $26(|6-4|)$ & $16(7-28)$ & $<0.001$ \\
\hline \multicolumn{4}{|l|}{ Number of asthma-related hospitalizations } \\
\hline Lifetime, mean (SD), median (IQR) & $\begin{array}{l}4.0(10.0) \\
1.0(0.0-4.0)\end{array}$ & $\begin{array}{l}4.7(7.2) \\
2.0(0.0-5.0)\end{array}$ & 0.01 \\
\hline Previous 12 months, mean (SD), median (IQR) & $\begin{array}{l}0.4(1.0) \\
0.0(0.0-0.0)\end{array}$ & $\begin{array}{l}\text { I.2(6.5), } \\
0.0(0.0-1.0)\end{array}$ & 0.17 \\
\hline Lifetime history of asthma-related ICU hospitalizations, $\mathrm{n}(\%)$ & $94(26)$ & $27(32)$ & 0.35 \\
\hline Previous 12-month history of emergency department visits, $\mathrm{n}(\%)$ & $|7|(48)$ & $56(66)$ & 0.004 \\
\hline \multicolumn{4}{|l|}{ Frequency of asthma attacks, ${ }^{\mathrm{a}} \mathrm{n}(\%)$} \\
\hline None & $96(27)$ & $14(17)$ & 0.02 \\
\hline$<\mathrm{l} / \mathrm{month}$ & $102(29)$ & $17(20)$ & \\
\hline$<$ I/week & $30(9)$ & $10(12)$ & \\
\hline Several times a week & $71(20)$ & $23(27)$ & \\
\hline Daily & $53(15)$ & $21(25)$ & \\
\hline Previous 12-month history of asthma exacerbations, $\mathrm{n}(\%)$ & $199(56)$ & $85(100)^{\mathrm{a}}$ & $<0.001$ \\
\hline \multicolumn{4}{|l|}{ Number of asthma exacerbations in previous 12 months, } \\
\hline Mean (SD), median (IQR) & $\begin{array}{l}2.7(4.0) \\
\text { I.0 } \\
(0.0-4.0)\end{array}$ & $\begin{array}{l}6.9(4.1), \\
6.0(3.0-10.0)\end{array}$ & $<0.001$ \\
\hline $0, \mathrm{n}(\%)$ & $157(44)$ & $0(0)$ & $<0.001$ \\
\hline $\mathrm{I}, \mathrm{n}(\%)$ & $54(15)$ & $0(0)$ & \\
\hline $2, \mathrm{n}(\%)$ & $26(7)$ & $12(14)$ & \\
\hline$\geq 3, \mathrm{n}(\%)$ & $119(33)$ & $73(86)$ & \\
\hline Median duration of asthma exacerbations, days (IQR) & $7.0(5.0-10.0)$ & $8.0(5.0-10.0)$ & 0.19 \\
\hline \multicolumn{4}{|l|}{ Level of asthma control, $n(\%)$} \\
\hline Optimal & $81(23)$ & $4(5)$ & $<0.001$ \\
\hline Suboptimal & $107(30)$ & $10(12)$ & \\
\hline Not optimal & $164(47)$ & $71(84)$ & \\
\hline
\end{tabular}

Notes: anclusion criterion.

Abbreviations: COBRA, Asthma and Bronchial Obstruction Cohort; ICU, intensive care unit; IQR, interquartile range. 
Table 3 Pulmonary function tests for patients with severe asthma at study inclusion

\begin{tabular}{|c|c|c|c|}
\hline Pulmonary function tests & $\begin{array}{l}\text { Benralizumab- } \\
\text { ineligible patients } \\
(n=356)\end{array}$ & $\begin{array}{l}\text { Benralizumab- } \\
\text { eligible patients } \\
(n=85)\end{array}$ & $P$-value \\
\hline Mean FEV, before BD, L (SD) & $2.11(0.8 I)$ & $1.99(0.61)$ & 0.34 \\
\hline Mean predicted FEV, before BD, \% (SD) & $76(24)$ & $70(18)$ & 0.03 \\
\hline Mean FEV,/FVC, \% (SD) & $66(13)$ & $65(13)$ & 0.24 \\
\hline Reversibility ${ }^{\mathrm{a}}$ [yes], n (\%) & $53(19)$ & $21(30)$ & 0.05 \\
\hline
\end{tabular}

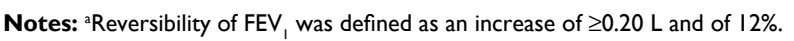

Abbreviations: $\mathrm{BD}$, bronchodilator; $\mathrm{FEV}_{1}$, forced expiratory volume in I second; FVC, forced vital capacity.

patients but these differences did not reach statistical significance (Table 4). At study inclusion, 6 (7\%) benralizumabeligible patients and $28(8 \%)$ benralizumab-ineligible patients were receiving omalizumab ( $P=1$; Table 4$)$. During the one-year follow-up period, these numbers increased to 48 $(57 \%)$ and 104 (29\%) patients in the benralizumab-eligible and -ineligible groups, respectively $(P=0.01)$.

For the 12-month follow-up period, data were missing for $22(26 \%)$ benralizumab-eligible patients and $90(25 \%)$ benralizumab-ineligible patients for the number of asthma exacerbations, asthma-related visits to emergency departments, and hospitalizations. Mean (range) follow-up periods for benralizumab-eligible and -ineligible patients were 364 (274-455) days and 374 (277-456) days, respectively ( $P=0.11$ ). Benralizumab-eligible patients had a greater mean incidence of asthma exacerbations (3.9/year vs 2.2/year; $P<0.001)$ and asthma-related hospitalizations $(0.19 /$ year vs $0.09 /$ year; $P=0.02$ ) compared with benralizumab-ineligible patients (Table 5 and Figure 2). The percentage of benralizumab-eligible patients who visited the emergency department was greater than that of benralizumab-ineligible patients $(40 \%$ vs $25 \% ; P=0.03$; Table 5). Median blood eosinophil counts remained greater than 300 cells $/ \mu \mathrm{L}$ for benralizumab-eligible patients throughout the 12-month follow-up period (Table 6).

\section{Discussion}

This retrospective analysis of adult patients with asthma in France enrolled in the COBRA study characterized patients who would potentially be eligible for benralizumab treatment. Based on the eligibility criteria that were used for the SIROCCO and CALIMA phase III randomized controlled trials, ${ }^{11,12}$ approximately $20 \%$ of patients with severe asthma in this analysis were eligible for benralizumab treatment. In SIROCCO and CALIMA, eligibility criteria included a baseline blood eosinophil count of $\geq 300$ cells $/ \mu \mathrm{L}$. In a post-hoc analysis of benralizumab-responsive patients in SIROCCO/ CALIMA, ${ }^{16,17}$ benralizumab improved lung function and total asthma symptom score and decreased annual asthma exacerbation rate compared with placebo for patients with blood eosinophil counts $\geq 150$ cells $/ \mu \mathrm{L}$. If a blood eosinophil count of $\geq 150$ cells $/ \mu \mathrm{L}$ at study inclusion had been used in this analysis of COBRA patients, the benralizumabeligible population would have increased to $29 \%$. Oral corticosteroids decrease blood eosinophil counts. ${ }^{18}$ In the ZONDA trial, ${ }^{19}$ benralizumab was shown to be efficacious in patients with severe asthma receiving high-dosage ICS/ LABA and oral corticosteroids, and with blood eosinophil counts $\geq 150$ cells $/ \mu \mathrm{L}$. If we had expanded the benralizumabeligibility criteria in the current study to include patients who were receiving oral corticosteroids and had blood eosinophil counts of $\geq 150$ cells $/ \mu \mathrm{L}$, we also would have captured a larger benralizumab-eligible population.

COBRA is a 10 -year prospective, noninterventional, observational study that began in 2008. Treatments recommended for asthma in 2008 (eg, medium- or high-dosage ICS/LABA, leukotriene modifiers and sustained-release theophylline, GINA step 4 regimens, and low-dosage oral glucocorticosteroids and anti-immunoglobulin E [ $\operatorname{IgE}]$ treatments as GINA step 5 regimens) are still widely used and recommended today. ${ }^{20}$ In recent years, biologics such as anti-IL-5 antibodies have been added to this repertoire. ${ }^{21}$ At study inclusion and during the 12-month observation period in our study, benralizumab-eligible patients had a greater frequency of hospitalizations, emergency department visits, and asthma exacerbations compared with the general population of study-eligible patients. The frequency of asthma attacks was also greater for benralizumab-eligible patients at study inclusion compared with study-eligible patients. It is clear new therapeutics to improve disease control for patients with severe, eosinophilic asthma are needed.

In addition to benralizumab, there are currently three biologics approved in Europe for the treatment of asthma. Omalizumab (Genentech Inc., South San Francisco, CA, USA) is a humanized anti-IgE monoclonal antibody approved as add- 


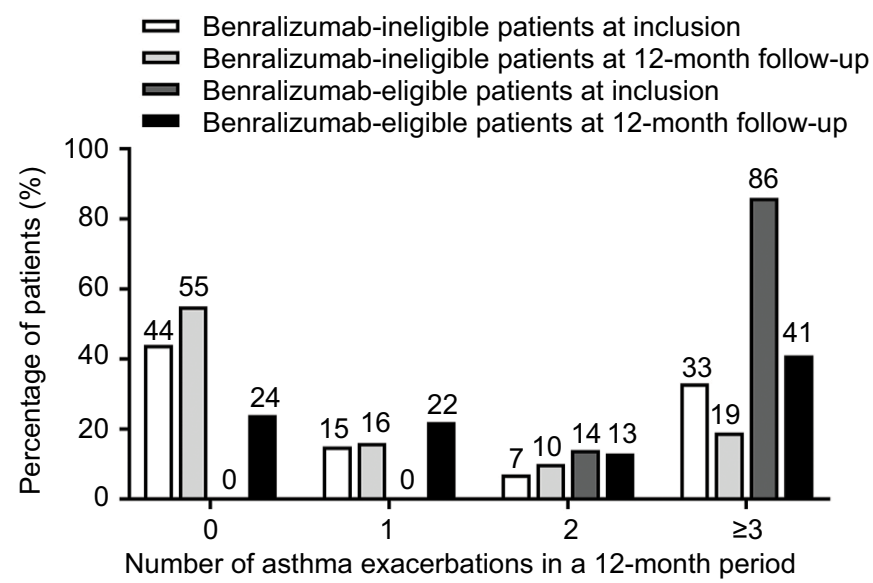

Figure 2 Number of asthma exacerbations in a 12-month period before (inclusion) and 12-month period after (follow-up) index date for benralizumab-ineligible and benralizumab-eligible patients.

Table 4 Allergy-related comorbidities and asthma treatments at study inclusion

\begin{tabular}{|c|c|c|c|}
\hline Comorbidities and asthma treatments & $\begin{array}{l}\text { Benralizumab-ineligible patients } \\
(n=356)\end{array}$ & $\begin{array}{l}\text { Benralizumab-eligible patients } \\
(n=85)\end{array}$ & $P$-value \\
\hline \multicolumn{4}{|l|}{ Allergy-related comorbidities, n (\%) } \\
\hline Sinusitis & $117(33)$ & $34(40)$ & 0.25 \\
\hline History of sinus surgery & $50(14)$ & $21(25)$ & 0.02 \\
\hline Nasal polyposis & $79(22)$ & $36(42)$ & 0.003 \\
\hline Allergic rhinitis & $237(67)$ & $53(62)$ & 0.44 \\
\hline Conjunctivitis & $124(35)$ & $18(21)$ & 0.01 \\
\hline Eczema & $87(24)$ & $19(22)$ & 0.78 \\
\hline Urticaria & $62(17)$ & $13(15)$ & 0.75 \\
\hline \multicolumn{4}{|l|}{ Positive skin tests } \\
\hline Pollens & $95(35)$ & $17(25)$ & 0.11 \\
\hline House dust mites & $129(48)$ & $24(35)$ & 0.06 \\
\hline Alternaria & $31(12)$ & $3(4)$ & 0.11 \\
\hline Aspergillus & $22(9)$ & $I(2)$ & 0.06 \\
\hline Cladosporium & $12(5)$ & $0(0)$ & 0.08 \\
\hline SABA, n (\%) & $332(94)$ & $82(97)$ & 0.44 \\
\hline LABA, n (\%) & $342(97)$ & $85(100)$ & 0.08 \\
\hline ICS, n (\%) & $350(98)$ & $85(100)$ & 0.60 \\
\hline LAMA, n (\%) & $46(13)$ & $18(2 \mid)$ & 0.06 \\
\hline ICS/LABA, n (\%) & $342(96)$ & $85(100)$ & 0.08 \\
\hline ICS/LABA/LAMA, ${ }^{\mathrm{a}} \mathrm{n}(\%)$ & $42(12)$ & $18(21)$ & 0.03 \\
\hline Median daily dosage of ICS, ${ }^{b} \mu \mathrm{g}$ (range) & $2,000(1,000-2,000)$ & $2,000(1,500-8,000)$ & $<0.001$ \\
\hline Oral corticosteroids, $\mathrm{n}(\%)$ & $67(19)$ & $23(27)$ & 0.13 \\
\hline Median daily dosage of OCS, ${ }^{b} \mathrm{mg}$ (range) & $20.0(15.0-40.0)$ & $20.0(2.0-80.0)$ & 0.7 \\
\hline Antileukotriene agents, $\mathrm{n}(\%)$ & $110(31)$ & $39(47)$ & 0.01 \\
\hline Theophylline, n (\%) & $13(4)$ & $3(4)$ & 1 \\
\hline Anti-lgE (omalizumab), n (\%) & $28(8)$ & $6(7)$ & I \\
\hline
\end{tabular}

Notes: aPatients receiving ICS/LABA/LAMA are represented in the ICS/LABA, ICS, LABA, and LAMA categories as well. ${ }^{b}$ Computed for patients who received corticosteroids. Abbreviations: ICS, inhaled corticosteroids; IgE, immunoglobulin E; LABA, long-acting $\beta_{2}$-agonists; LAMA, long-acting muscarinic antagonist; OCS, oral corticosteroids; SABA, short-acting $\beta_{2}$-agonists.

on therapy for patients $\geq 6$ years of age with severe persistent, uncontrolled asthma and either a positive skin test or in-vitro reactivity to a perennial aeroallergen. ${ }^{22}$ Mepolizumab and reslizumab are anti-IL-5 monoclonal antibodies approved as add-on maintenance treatment for patients with severe asthma and an eosinophilic phenotype. ${ }^{23,24}$ In the observational, cross- sectional IDEAL study of patients with severe asthma from six countries in Australia, Europe (including France), and North America, $20 \%$ of patients were eligible for mepolizumab, $5 \%$ for reslizumab, and $31-41 \%$ for omalizumab. ${ }^{25}$ For mepolizumab and reslizumab, eligibility requirements included $\geq 2$ (mepolizumab) or $\geq 1$ (reslizumab) asthma exacerbations 
Table 5 Asthma exacerbations, emergency department visits, and hospitalizations during 12-month follow-up period

\begin{tabular}{|c|c|c|c|}
\hline $\begin{array}{l}\text { Asthma exacerbations, } \\
\text { emergency department visits, and } \\
\text { hospitalizations }\end{array}$ & $\begin{array}{l}\text { Benralizumab- } \\
\text { ineligible patients } \\
(n=266)\end{array}$ & $\begin{array}{l}\text { Benralizumab- } \\
\text { eligible patients } \\
(n=63)\end{array}$ & $P$-value \\
\hline$\geq \mathrm{I}$ emergency department visit, $\mathrm{n}(\%)$ & $67(25)$ & $25(40)$ & 0.03 \\
\hline \multicolumn{4}{|l|}{ Asthma-related hospitalizations, $\mathrm{n} /$ year $^{\mathrm{a}}$} \\
\hline Mean (SD), median (IQR) & $\begin{array}{l}0.09(0.42), \\
0(0-0)\end{array}$ & $\begin{array}{l}0.19(0.66), \\
0(0-0)\end{array}$ & 0.02 \\
\hline$\geq \mathrm{I}, \mathrm{n}(\%)$ & $15(5.6)$ & $7(I I . I)$ & 0.16 \\
\hline$\geq 2, \mathrm{n}(\%)$ & $7(2.6)$ & $3(4.8)$ & 0.41 \\
\hline \multicolumn{4}{|l|}{ Asthma exacerbations, $\mathrm{n} /$ year $^{\mathrm{a}}$} \\
\hline Mean (SD), median (IQR) & $\begin{array}{l}2.2(5.5) \\
0(0-1.9)\end{array}$ & $\begin{array}{l}3.9(8.6) \\
1.9(0.8-4.2)\end{array}$ & $<0.001$ \\
\hline$\geq \mathrm{I}, \mathrm{n}(\%)$ & $|2|(45.5)$ & $48(76.2)$ & $<0.001$ \\
\hline$\geq 2, \mathrm{n}(\%)$ & $78(29.3)$ & $34(54.0)$ & $<0.001$ \\
\hline$\geq 3, \mathrm{n}(\%)$ & $51(19.2)$ & $26(4 \mid .3)$ & $<0.001$ \\
\hline$\geq 4, \mathrm{n}(\%)$ & $40(15.0)$ & $20(31.7)$ & $<0.003$ \\
\hline
\end{tabular}

Notes: aHospitalization and asthma exacerbation frequencies equal the number of hospitalizations and exacerbations during follow-up divided by the length of follow-up. Abbreviation: IQR, interquartile range.

Table 6 Eosinophil counts during 12-month follow-up period for patients with a baseline eosinophil count of $\geq 300$ cells/ $\mu \mathrm{L}$

\begin{tabular}{|c|c|c|c|}
\hline \multirow{2}{*}{$\begin{array}{l}\text { Eosinophils at baseline } \\
\geq 300 / \mu \mathrm{L}\end{array}$} & \multicolumn{3}{|c|}{ 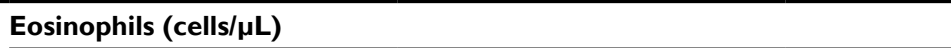 } \\
\hline & Visit I & Visit 2 & Visit 3 \\
\hline Benralizumab-ineligible patients, ${ }^{a}$ median (IQR) & $480(375-750)$ & $390(260-595)$ & $369(260-680)$ \\
\hline Benralizumab-eligible patients, ${ }^{b}$ median (IQR) & $490(390-710)$ & $390(233-670)$ & $340(190-420)$ \\
\hline
\end{tabular}

Notes: ${ }^{a} n=174 .{ }^{b} n=85$.

Abbreviation: IQR, interquartile range.

requiring oral corticosteroids, emergency department visits, or hospitalizations in the previous 12 months, and blood eosinophil counts of $\geq 150$ cells $/ \mu \mathrm{L}$ at study visit or $\geq 300$ cells $/ \mu \mathrm{L}$ in the previous 12 months (mepolizumab) or $\geq 400$ cells $/ \mu \mathrm{L}$ (reslizumab). Omalizumab qualification criteria included a threshold asthma exacerbation frequency ( $\geq 1$ or $\geq 2$ ), high IgE concentrations, and positive allergy test. The percentage of patients with severe asthma enrolled in the COBRA study who would be eligible for benralizumab is consistent with those observed for mepolizumab and reslizumab.

This study had certain limitations. First, the study was not a random sampling of patients with severe asthma in France, for the enrollment process involved pulmonologists in specialized university hospitals. Second, the study took place before the approval of mepolizumab and reslizumab, so we could not undertake an analysis of patients who were treated with these agents and were also eligible for benralizumab treatment. Third, we did not analyze patients treated with omalizumab because the duration of treatment and reasons for cessation were not recorded in the case report forms. Fourth, approximately $25 \%$ of patients had missing data on disease burden during the look-forward period.

\section{Conclusion}

Approximately $20 \%$ of patients in this real-life cohort study were eligible for treatment with benralizumab, a novel agent for the treatment of uncontrolled, severe, eosinophilic asthma. These patients had more frequent asthma exacerbations and symptoms and worse asthma control than the benralizumab-ineligible population of patients with severe asthma. Understanding prevalence and clinic characteristics of patients who would be responsive to benralizumab will be important for clinicians in their decisions to treat severe, uncontrolled asthma with an eosinophilic phenotype.

\section{Data sharing statement}

The research protocol developed for this study and data for this retrospective analysis are available upon request from the corresponding author.

\section{Acknowledgments}

Editorial support was provided by Francis J Golder, BVSc, $\mathrm{PhD}$, of JK Associates, Inc., and Michael A Nissen, ELS, of AstraZeneca. This study was funded by AstraZeneca. 


\section{Author contributions}

All authors contributed to the study design, data analysis and interpretation, and preparation of this manuscript and agree to be accountable for all aspects of the work.

\section{Disclosure}

Michel Aubier received research grants from AstraZeneca to conduct the study. Gabriel Thabut and Caroline FabryVendrand are employees of AstraZeneca. The authors report no other conflicts of interest in this work.

\section{References}

1. Delmas MC, Fuhrman C, for the Epidemiology and Research Group SPLF Clinic. [Asthma in France: a review of descriptive epidemiological data]. Rev Mal Respir. 2010;27(2):151-159. French.

2. To T, Stanojevic S, Moores G, et al. Global asthma prevalence in adults: findings from the cross-sectional world health survey. BMC Public Health. 2012;12:204.

3. Chung KF, Wenzel SE, Brozek JL, et al. International ERS/ATS guidelines on definition, evaluation and treatment of severe asthma. Eur Respir J. 2014;43(2):343-373.

4. Peters SP, Ferguson G, Deniz Y, Reisner C. Uncontrolled asthma: a review of the prevalence, disease burden and options for treatment. Respir Med. 2006;100(7):1139-1151.

5. Gadenne S, Pribil C, Chouaid C, Vergnenegre A, Detournay B. Le coût de l'asthme en France et les implications économiques du niveau de contrôle [The costs of asthma in France and the economic implications of its level of control]. Rev Mal Respir. 2011;28(4):419-426. French.

6. Durham AL, Caramori G, Chung KF, Adcock IM. Targeted antiinflammatory therapeutics in asthma and chronic obstructive lung disease. Transl Res. 2016;167(1):192-203.

7. Price D, Wilson AM, Chisholm A, et al. Predicting frequent asthma exacerbations using blood eosinophil count and other patient data routinely available in clinical practice. J Asthma Allergy. 2016;9:1-12.

8. Talini D, Novelli F, Bacci E, et al. Sputum eosinophilia is a determinant of FEV1 decline in occupational asthma: results of an observational study. BMJ Open. 2015;5(1):e005748.

9. Belda J, Parameswaran K, Lemière C, Kamada D, O’Byrne PM, Hargreave FE. Predictors of loss of asthma control induced by corticosteroid withdrawal. Can Respir J. 2006;13(3):129-133.

10. Kolbeck R, Kozhich A, Koike M, et al. MEDI-563, a humanized anti-IL-5 receptor alpha $\mathrm{mAb}$ with enhanced antibody-dependent cellmediated cytotoxicity function. J Allergy Clin Immunol. 2010;125(6): 1344-1353.

11. FitzGerald JM, Bleecker ER, Nair P, et al. Benralizumab, an antiinterleukin-5 receptor $\alpha$ monoclonal antibody, as add-on treatment for patients with severe, uncontrolled, eosinophilic asthma (CALIMA): a randomised, double-blind, placebo-controlled phase 3 trial. Lancet. 2016;388(10056):2128-2141.
12. Bleecker ER, FitzGerald JM, Chanez P, et al. Efficacy and safety of benralizumab for patients with severe asthma uncontrolled with highdosage inhaled corticosteroids and long-acting $\beta_{2}$-agonists (SIROCCO): a randomised, multicentre, placebo-controlled phase 3 trial. Lancet. 2016;388(10056):2115-2127.

13. Fasenra ${ }^{\mathrm{TM}}$. (benralizumab) Summary of product characteristics. Available from: http://www.ema.europa.eu/docs/en_GB/document_library/ EPAR_-_Product_Information/human/004433/WC500245331.pdf. Accessed April 5, 2018.

14. Epidemiologie - France Portal. COBRA - Asthma and Airway Obstruction Cohort: Clinicobiological Cohort Follow-up; 2014. Available from: https://epidemiologie-France.aviesan.fr/en/epidemiology/records/ asthma-and-airway-obstruction-cohort-clinicobiological-cohortfollow-up. Accessed October 12, 2017.

15. Pretolani M, Soussan D, Poirier I, Thabut G, Aubier M, on behalf of the COBRA Study Group. Clinical and biological characteristics of the French COBRA cohort of adult subjects with asthma. Eur Respir J. 2017;50(2):1700019.

16. FitzGerald JM, Bleecker ER, Menzies-Gow A, et al. Predictors of enhanced response with benralizumab for patients with severe asthma: pooled analysis of the SIROCCO and CALIMA studies. Lancet Respir Med. 2018;6(1):51-64.

17. Goldman M, Hirsch I, Zangrilli JG, Newbold P, Xu X. The association between blood eosinophil count and benralizumab efficacy for patients with severe, uncontrolled asthma: subanalyses of the Phase III SIROCCO and CALIMA studies. Curr Med Res Opin. 2017;33(9):1605-1613.

18. Austin D, Pouliquen I, Keene O, Yancey S. Blood eosinophil dose response to oral corticosteroids in a population of patients with severe asthma. Eur Respir J. 2016;48:PA1110.

19. Nair P, Wenzel S, Rabe KF, et al. Oral glucocorticoid-sparing effect of benralizumab in severe asthma. NEnglJMed.2017;376(25):2448-2458.

20. Bateman ED, Hurd SS, Barnes PJ, et al. Global strategy for asthma management and prevention: GINA executive summary. Eur Respir J. 2008;31(1):143-178.

21. Global Initiative for Asthma. Global strategy for asthma management and prevention; 2017. Available from: http://ginasthma.org/2017-ginareport-global-strategy-for-asthma-management-and-prevention/. Accessed October 12, 2017

22. Xolair ${ }^{\text {B }}$. (omalizumab) Summary of product characteristics. Available from: http://www.ema.europa.eu/docs/en_GB/document_library/ EPAR_-_Product_Information/human/000606/WC500057298.pdf. Accessed October 12, 2017.

23. Nucala ${ }^{\circledR}$. (mepolizumab) Summary of product characteristics. Available from: http://www.ema.europa.eu/docs/en_GB/document_library/ EPAR_-_Product_Information/human/003860/WC500198037.pdf. Accessed October 12, 2017

24. CINQAERO ${ }^{\circledR}$. (reslizumab) Summary of product characteristics. Available from: http://www.ema.europa.eu/docs/en_GB/document_library/ EPAR_-_Product_Information/human/003912/WC500212250.pdf. Accessed October 12, 2017

25. Albers FC, Müllerová H, Gunsoy NB, et al. Biologic treatment eligibility for real-world patients with severe asthma: The IDEAL study. JAsthma. 2018;55(2):1-9.
Journal of Asthma and Allergy

\section{Publish your work in this journal}

The Journal of Asthma and Allergy is an international, peer-reviewed open access journal publishing original research, reports, editorials and commentaries on the following topics: Asthma; Pulmonary physiology; Asthma related clinical health; Clinical immunology and the immunological basis of disease; Pharmacological interventions and

\section{Dovepress}

new therapies. This journal is included in PubMed. The manuscript management system is completely online and includes a very quick and fair peer-review system, which is all easy to use. Visit http://www. dovepress.com/testimonials.php to read real quotes from published authors. 